\title{
RIGHT TO COUNSEL AT SCENE-OF-THE-CRIME IDENTIFICATIONS
}

George McCann investigated strange noises and observed a man leaving a shoeshine shop that apparently had been broken into. $\mathrm{He}$ immediately reported the incident to a nearby police station. Two officers promptly spotted a man fitting a radioed description, and they arrested him after a short chase. They took him directly to the shoeshine shop where McCann identified him as the man he had seen leaving the shop. This identification was admitted as evidence at trial. On appeal his conviction was affirmed in Russell $v$. United States. ${ }^{1}$

United States $v$. Wade ${ }^{2}$ requires the presence of counsel at postindictment lineups, but the Russell court declined to extend the Wade rule to on-the-scene identifications made promptly after the commission of a crime. The court found that the delay involved in obtaining the presence of counsel would not only prevent the expeditious "release of innocent suspects," but would also "diminish the reliability of any identification obtained." They considered these to be "substantial countervailing policy considerations" justifying a limitation of $W a d e .^{3}$

\section{A. The Rule of Wade}

In Wade the Supreme Court affirmed the Fifth Circuit's reversal of a conviction ${ }^{4}$ resulting from an in-court identification, which followed a post-indictment lineup ${ }^{5}$ conducted almost eight months ${ }^{6}$ after the crime. ${ }^{7}$ Wade's appointed counsel had not been informed of the lineup and, consequently, was not present at the proceedings. The Court stated that the guarantees of the sixth amendment apply to

1 No. 21,571 (D.C. Cir., Jan. 24, 1969).

2388 U.S. 218 (1967).

3 No. 21,571 at 7 (quoting United States v. Wade, 388 U.S. 218, 237 (1967))

In his concurring opinion, Judge Danaher relied on the Omnibus Crime Control \& Safe Streets Act of 1968, \$701(a), 18 U.S.C.A. \$ 3502 (Supp. 1969), which provides that eyewitnesses' testimony that the witness "saw the accused commit or participate in" the crime shall be admissible in evidence in any federal court. The statute was enacted to counter the effects of Wade. See S. REP. No. 1097, 90th Cong., 2d Sess. 52 (1968).

4 The circuit court opinion is reported at 358 F.2d 557 (5th Cir. 1966).

5In this Comment, the term "lineup" describes a situation in which the witness views several persons at one time, often under controlled viewing or lighting conditions. The term "showup" describes a confrontation at a police station house, arranged by the police, between only the suspect and the identifying witness. See 388 U.S. at 229,230 n.13. See other definitions in note 23 infra.

${ }^{6}$ See 388 U.S. at 220.

7 The Court remanded the case for a determination of whether the in-court identifcations of Wade were based on observations other than at the tainted lineup and thus still admissible, or whether, if not independently admissible, their admission was nevertheless harmless error. Id. at 242. 
critical stages ${ }^{8}$ of pretrial proceedings in which the prosecution confronts the accused, ${ }^{0}$ and held that one such critical stage is the lineup, because of its almost conclusive effect on the later in-court identification.

The Court reasoned that since police may consciously or unconsciously suggest which lineup participant is the suspect, the process could substantially prejudice the accused. ${ }^{10}$ The secrecy of lineups prevents an accurate appraisal, by either defense counsel or the court, of the procedure used to identify the accused. Unless the police keep records of the proceedings when questioned by the defense, they will be unable to reconstruct the events which transpired. More important, the accused most likely cannot himself adequately describe unfairness that occurred, lacks credibility in the eyes of the jury, ${ }^{11}$ or will be discouraged from testifying altogether for fear that past convictions will be brought to the jury's attention to impeach his testimony. Consequently, as an individual he will not be able effectively to attack the reliability of an in-court identification tainted by a prior confrontation. ${ }^{12}$

However, a lawyer for the accused present at the lineup could certainly detect more obvious suggestions by the police, if not all unfair suggestions. His presence would also tend to discourage unfair and prejudicial practices; and he may be able to persuade the police to correct these abuses. Failing this, he could effectively present to the fact-finder the conditions under which the lineup was conducted. ${ }^{13}$

Beyond possible police abuse, the Court stressed the inherent unreliability of all eyewitness identifications. ${ }^{14}$ Counsel's presence could correct some of the problems leading to this unreliability. For instance, counsel present at the lineup could recognize symptoms of emotional stress tending to impair a witness's objectivity. Finally, the

8 The Court defined a critical stage as "any pretrial confrontation of the accused [in which] the presence of his counsel is necessary to preserve the defendant's basic right to a fair trial ...." Id. at 227 (emphasis in original).

${ }^{9} I d$. at 226.

10 The Court decried the evils of mistaken identification caused by "the degree of suggestion inherent in the manner in which the prosecution presents the suspect to witnesses for pretrial identification." Id. at 228.

The police practices which constituted unfair and prejudicial suggestions to a witness of a suspect's identity included: displaying an Oriental suspect with 5 Caucasians; requiring all participants to try on clothing similar to that worn during the crime, but giving properly fitting clothing only to the suspect; presenting the suspect alone before the witness after informing the witness that the offender had been caught. Id. at 230-35. See Foster v. California, 89 S. Ct. 1127 (1969) (similar practices).

11388 U.S. at $230-32$.

12 Id. at 235 .

13 The manner in which counsel presents to the fact-finder the circumstances under which the police conducted the lineup may raise problems, such as whether counsel should take the witness stand. See Comment, Lawyers and Lineups, 77 YALE L.J. 390, 396-98 (1967).

14388 U.S. at 228, 235. Although all eyewitness identifications may be inherently unreliable, even without unfair police suggestions, until all such evidence is excluded courts can do little more than formulate standards of police conduct to minimize the risk of suggestiveness. 
Court found " $[\mathrm{n}] \mathrm{o}$ substantial countervailing policy considerations . . . against the requirement of the presence of counsel." 15 In light of these considerations, the Wade Court held that a post-indictment lineup is a critical stage of pretrial proceedings during which the sixth amendment requires presence of counsel, unless the right is effectively waived..$^{10}$

The Wade court was concerned with station house identification procedures, but there are other unfair practices beyond the immediate circumstances of a lineup. The participants may be suspects known for the particular type of crime under investigation. ${ }^{17}$ Other participants may be persons identified by an informant. ${ }^{18}$ The informant might be highly reliable in most cases, but personal antagonisms could enter into a particular situation; unfair suggestions by the police relying on the informant's previous record of accuracy may also result in mistaken identification. Still other participants might be prisoners awaiting trial or release on bail, who themselves are subject to mistaken identification. ${ }^{19}$ Consequently, a number of suspects suggested to wit-

15 Id. at 237.

$16 \mathrm{Id}$. The Court also held that a lineup does not violate the accused's privilege against self-incrimination. Id. at 221-23.

In Gilbert v. California, 388 U.S. 263, 269-74 (1967), the Supreme Court vacated a conviction derived from in-court identifications of the defendant by witnesses who had observed him at a lineup conducted without counsel, and who testified on crossexamination that they had identified him at the lineup. The Court remanded to determine whether the in-court identifications had a source independent of the lineup or whether their admission in evidence was harmless error. The testimony in court about the identification at the lineup was to be excluded unless there was no reasonable doubt that its admission was harmless. This requirement effectively excluded the testimony. Thus, Wade and Gilbert together exclude evidence tainted by a prior lineup conducted in the absence of the accused's counsel. See Comment, The Right to Contsel During Pretrial Identification Proceedings-An Exanination, $47 \mathrm{NkB}$. L. Rev. 740, 745 (1968).

In Stovall v. Denno, 388 U.S. 293 (1967), decided together with Wade and Gilbert, the Court held that Wade should only be applied prospectively. The petitioner Stovall had been identified by a stabbing victim, as she lay in her hospital bed following emergency surgery. Since the surgeons thought that the witness might die, Stovall, a Negro, was brought handcuffed to her room in the custody of several whites. Although this situation risked unfair suggestiveness, the Court felt that the identification did not violate due process because the "totality of the circumstances" demanded a confrontation before the witness died.

A due process "totality of the circumstances" test could be used to judge the propriety of an on-the-scene confrontation. However, the policeman reacting to the reported crime may not know all the circumstances and so would be unable to judge their totality. So broad a test also places very wide discretion in the hands of the police. Rather than rely on vague due process, this Comment suggests an explicit rule to govern on-the-scene confrontations. See text accompanying notes 44-50 infra.

17 If the police hold the lineup to identify a bank robber, certain participants might be persons with a criminal record of bank robbery, or persons whom the police have long suspected of being bank robbers.

18 Cf. Rugendorf v. United States, 376 U.S. 528 (1964) ; Smith v. United States, 358 F.2d 833 (D.C. Cir. 1966).

19 See Comment, Right to Counsel at Police Identification Proceedings: A Problem in Effective Implententation of an Expanding Constitution, 29 U. PITT. L. REv. 65,80 n. 92 (1967). In Crume v. Beto, 383 F.2d 36 (5th Cir. 1967), the defendant was arrested for drunkenness but was identified in a lineup, with a subsequent showup, as the robber of a liquor store. In State v. Wright, 274 N.C. 84, 161 S.E.2d 581 (1968), the defendant, arrested as a peeping tom, was identified in a showup as a rapist. 
nesses by the police are not arrested as a result of a thorough investigation which produce sufficient, independent evidence of guilt. ${ }^{20}$ Therefore, the probability that innocent suspects are identified through suggestion increases. Although the presence of counsel cannot in itself eliminate harassment, it may serve to discourage it by creating an opportunity for counsel to conduct interviews of participants which would reveal or suggest reasons they were selected for the lineup.

The requirement of counsel is in large part a condemnation of, and restraint upon, unfair police practices in identification proceedings. The question is, should this restraint extend beyond lineups? ${ }^{21}$

\section{B. Limiting the Wade Rule}

Prior to the Russell decision both state and federal courts struggled with the problem of applying $W$ ade to on-the-scene identifications. Reflecting the difficulty of the controversy, courts split on the issue. ${ }^{22}$ The Russell court first recognized that some language in Wade-that the sixth amendment requires "counsel at any pretrial confrontation" arranged by the police" 24 - seemed to cover Russell's case. They noted, too, that the Supreme Court stated that counsel was required

$20 \mathrm{~A}$ suspect placed in a lineup under these circumstances may try to raise the defense that the police lacked probable cause to arrest him, or to display him. However, an identification by a previously reliable informant who had fabricated plausible facts supporting his identification would be sufficient evidence to obtain a warrant if the police were unaware of the fabrication. See Rugendorf v. United States, 376 U.S. 528 (1964). When police display prisoners in a lineup, the circumstances of a prisoner's arrest can provide probable cause. E.g., Crume v. Beto, 383 F.2d 36 (5th Cir. 1967) (circumstances described in note 19 supra). Also, the police would have probable cause to seize promptly one or two persons found in the immediate vicinity of a crime after its commission, whenever these persons reasonably resemble an adequate description of the offender; see note 36 infra. Thus, the probable cause defense may in many cases fail.

21 The Wade court carefully pointed out that the presence of counsel at postindictment lineups was mandated by the inherent unreliability of eyewitness identification and the potential for police abuse of lineup procedures. The Court noted that the critical nature of a lineup could be mitigated by legislation or police regulations which eliminated possibilities of abuse. 388 U.S. at 239 . In an on-the-scene confrontation, there are equal possibilities for abuse. Moreover, the inherent unreliability of an eyewitness identification is likely to be heightened by his emotional involvement in the event. Yet there are significant countervailing policies here which did not appear in Wade. See text accompanying notes 33-40 infra. These policies suggest that Wade should not be extended to on-the-scene confrontations. However, to limit possibilities for abuse, this Comment suggests a rule to govern on-the-scene confrontations which could be promulgated by the legislature or local governments and which should eliminate the factors present in lineups which led the Wade court to find that post-indictment lineups were a critical stage of pretrial proceedings. See text accompanying notes 44-50 \& notes 44-50 infra.

22 Compare United States v. Davis, 399 F.2d 948 (2d Cir. 1968), and Commonwealth v. Bumpus, 238 N.E.2d 343 (Mass. 1968), with Rivers v. United States, 400 F.2d 935 (5th Cir. 1968), and United States v. Kinnard, No. 774-68 (D.D.C., Nov. 4,1968 ).

23 This Comment uses the term "confrontation" to describe a situation intentionally arranged by the police in which the identifying witness subsequent to the commission of the crime observes the suspect (and may or may not identify him). An "identification" occurs when the witness positively identifies the suspect as the offender or exonerates him. See other definitions in note 5 supra.

24 No. 21,571 at $3-4$. 
whenever his presence was "necessary to preserve the defendant's right to a fair trial ...." 25 and that the Court went on to say:

[T] he confrontation compelled by the State between the accused and the victim or witnesses to a crime to elicit identification evidence is peculiarly riddled with innumerable dangers and variable factors which might seriously, even crucially, derogate from a fair trial. . . .

. . . [R] isks of suggestion attend either [a lineup or a showup] and increase the dangers inhering in eyewitness identification. ${ }^{26}$

The Russell court recognized that an on-the-scene showup may seriously prejudice the defendant's case since the showup is the most suggestive confrontation used by the police. ${ }^{27}$ The witness is confronted by a person who may appear nervous or frightened (as would many persons suddenly stopped on the street and detained by the police), and who may seem to the witness to be an obvious villain since he has been seized. In addition, the witness may feel compelled to assist the police or may want to reward them for their efforts by confirming their suspicions. Furthermore, the witness may be emotionally upset.

The Russell court then balanced this high degree of suggestiveness inherent in a one-man showup against the witness's reliability. The court considered his memory to be most reliable immediately following the crime. The offender's features may at first be clear in the witness's "mind's eye," but quickly fade thereafter. Any verbalization is an approximation of that image, and delay in identification reduces the likelihood that the identification is based on this clear, inarticulate memory and increases the chance of relying on the more or less inaccurate verbalization. Since an increase in the time period between the crime and the confrontation decreases the witness's ability to make an accurate identfication, the court decided that the interest in accuracy outweighed the suggestibility inherent in an on-the-scene confrontation, and that the witness's reliability was a substantial countervailing policy favoring a limitation on the $W$ ade requirement of counsel. ${ }^{28}$

Although the Wade court's concern with unfair suggestions perhaps implies that the rule was formulated to obtain reliable witnesses,

25388 U.S. at 227.

26 Id. at 228-29 (footnote omitted).

27 P. Wali, Eye-Witness Identification in Criminal Cases 27 (1965).

28 Additionally, the court found that the suggestibility in this case was not such as to deprive the defendant of due process. It recognized, however, that courts must consider the absence of counsel among the "totality of circumstances" bearing on the issue of due process, particularly where a potentially suggestive confrontation is involved. 
the court in fact couched its rule in terms of a fair trial $:{ }^{29}$ that is, the right to meaningful cross-examination and effective assistance of counsel. $^{30}$ The finder of fact determines the reliability of the witness's identification. Counsel's presence at the lineup guarantees that the factfinder has all relevant evidence available in making his determination. Since the $W$ ade court treated the reliability of the witness as a question of fact to be judged by the fact-finder in light of the circumstances surrounding the identification, the court in Russell may have relied too heavily on early access to the witness's memory as a substantial countervailing policy. And even if the $W$ ade opinion does not preclude reliance on a witness's vivid memory (a factor absent from the Wade facts) as a substantial countervailing policy, there are other considerations that argue against substantial reliance on a fresh memory.

The foremost of these factors, which the Russell court did not consider, is the effect counsel could have on the suggestiveness of an on-the-scene confrontation. The degree to which suggestiveness is present in each on-the-scene confrontation would seem to turn on the witness's mental state, the suspect's emotional appearance, and the words and actions of the police. These factors may be forever lost if counsel cannot observe the confrontation. Once the witness makes his identification and the police terminate their search, it is highly unlikely that the witness will thereafter recant his identification. ${ }^{31}$ The surprise and nervousness of an innocent suspect may render him unable to give a full account of the confrontation to his counsel. If the police were deliberately suggestive or if they coerced the witness's identification, they will not admit it; if their influence on the witness was unconscious, they will not even recognize its existence. Consequently, since many on-the-scene confrontations may be unreliable, counsel's presence at the confrontations would serve to reduce or identify the prejudice of unfair suggestiveness used against the suspect, and thus preserve the suspect's right to effective assistance of counsel and crossexamination. Furthermore, a delay of one or two days during which time counsel could be assigned (at least for the lineup) would not impair a witness's memory to the extent that an element of reliability would be lost in the passage of time. ${ }^{32}$

29 The Court stated that the sixth amendment guarantees to the accused the presence of counsel whenever "counsel's absence might derogate from the accused's right to a fair trial." Id. at 226 .

$30 \mathrm{Id}$. at $227,235$.

31 This unlikelihood goes beyond the typical in-court identification, where the witness knows that the accused is sitting at the defense table, to encompass a witness's reluctance to disappoint the police, to display his own uncertainty, or to shoulder responsibility for a mistaken identity, the admission of which would strike down all efforts made in reliance on it.

32 Psychological experiments have demonstrated that persons viewing a particular shape retain for at least 3 weeks a remarkable ability to select that shape from a group of 10 shapes, some of which are quite similar to the shape viewed originally. Yet, there is a significant decline in a viewer's ability to reproduce that shape; within 2 
However, the Russell court found a second substantial countervailing policy consideration which may justify restriction of the Wade rule: "the desirability of expeditious release of innocent suspects . 33 The detention or arrest of innocent suspects is extremely inconvient, to say the least, to those detained, ${ }^{34}$ and it may also tend to hamper effective law enforcement by unnecessarily diverting police resources. Whether this policy consideration has sufficient force to support the Russell result in the absence of the reliability consideration may be determined by examining the conditions that would be created by an extension of the Wade rule to on-the-scene confrontations.

If counsel were required at all confrontations between a witness and a suspect, the police would have three alternatives. Conceivably, attorneys could ride in every squad car or remain on call in police headquarters and accompany police responding to a reported crime. However, the cost, administrative burden, and lack of willing attorneys make these two alternatives impractical if not impossible. A third possibility is the prohibition of on-the-scene confrontations with a concomitant requriement of a lineup attended by counsel for every confrontation..$^{35}$ This system may create problems. First, the police might want to seize every person in the vicinity of the crime who reasonably resembles the description given by the witness. ${ }^{36}$ However, if several persons fit the description of a single offender, a court might hold that the policeman lacked probable cause to arrest any of them without an identification. As a result, the offender may escape even though he could have been arrested were an identification permitted since an eye-witness identification would provide probable cause.

days, the reproductions are strikingly inaccurate. See Rock \& Englestein, $A$ Study of Memory for Visual Form, 72 AM. J. Psychol. 221 (1959); cf. Stricker \& Cooper, The Efficacy of the Benton Visual Retention Test at the "Very Superior" Intelligence Level, $68 \mathrm{~J}$. GEN. Psychol. 165 (1963). Consequently, the reliability of a witness's identification should not decrease significantly within a few days although any attempts at verbalization of his memory may reduce the accuracy of the resulting description.

33 No. 21,571 at 7.

34 In Philadelphia, a suspect is normally arraigned within 25 hours of his arrest. " $[\mathrm{H}]$ owever an identification is usvilly made prior to the arraignment." Reply to Questionnaire from Frank L. Rizzo, Police Commissioner, Philadelphia, Pennsylvania, to University of Pennsylvania Law Review, Feb. 26, 1969, on file in Biddle Law Library, University of Pennsylvania Law School (emphasis in original).

Not only will suspects be inconvenienced, but a potential for harassment also exists.

35 If the lineup is conducted within 1 or 2 days of the crime in order to take full advantage of the freshness of the witness's memory, when only one suspect has been arrested, the lineup may be as suggestive as a showup due to the difficulty of obtaining participants who resemble the suspect. Comment, note 19 supra, at $80 \& 80 \mathrm{n}$. 92 .

36 In Philadelphia, the description must be in sufficient detail to identify a particular individual, e.g., white, male, about 6 feet tall, light hair, wearing hornrimmed glasses; or, Negro, male, about 6 feet tall, wearing leather jacket with club

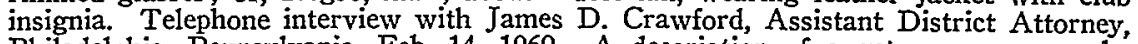
Philadelphia, Pennsylvania, Feb. 14, 1969, A description of a getaway car may be substituted for that of an individual, e.g., 1968 Corvette, blue, white license plate, smashed headlight. Telephone interview with Inspector Mangione, Philadelphia Police Department, Feb. 18, 1969. 
Where the actual offender has been promptly apprehended, ${ }^{37}$ the prohibition on immediate identification might cause a waste of valuable time and talent in an unnecessary continuation of the search. A continuing search with accompanying stop and frisks, or an additional arrest, may generate feelings of ill will and distrust of the police within the community, as well as claims of undue police harassment. Furthermore, an absolute prohibition might exclude on-the-scene confrontations that must be made immediately, such as an identification by a dying witness. $^{38}$ Therefore, these three alternatives, despite their appearance of providing aid to the suspect through counsel's presence at any confrontation, are either impractical, or would not solve but rather would exacerbate the problems of attaining fair and effective law enforcement, minimizing detention of innocent suspects, and preventing antagonism of the community.

Limiting the Wade rule so as not to extend to on-the-scene confrontations would not sacrifice many of the protections established by the requirement of counsel for identifications occurring well after the crime. To the extent that $W a d e$ raised an unarticulated bar to unfair police practices used prior to a lineup or showup, exempting on-thescene confrontations from the $W$ ade requirement of counsel does not undermine this prohibition. The on-the-scene confrontation of a suspect promptly seized by police contains much less potential for police malice and harassment than does a lineup. A prompt search and arrest within the vicinity of a crime does not permit a round-up of persons generally suspected or disliked by the police, or the use of persons already jailed. ${ }^{39}$ Since an extension of the Wade requirement of counsel to on-the-scene confrontations raises more problems than it solves, it would seem that the Russell court correcty held that prompt, on-thescene confrontations need not be conducted in the presence of counsel.40

\section{A Proposed Standard}

The Russell court did not articulate a standard that police can follow when deciding whether a confrontation is "on-the-scene." If an identification is made in the absence of counsel, valuable witness

37 Whether the actual offender will be apprehended depends to a certain extent on the promptness of the police response to a reported crime. See Comment, Police Discretion and the Judgment that a Crime Has Been Committed-Rape in Philadelphia, 117 U. PA. L. REv. 277, 282-86 (1968). If the police respond promptly, it is more likely that the actual offender will be among those apprehended.

38 However, an exception to the prohibition perhaps could be made for the extraordinary case. Cf. Stovall v. Denno, 388 U.S. 293 (1967).

30 This conclusion also applies to an innocent suspect identified by a hostile informant. If the informant's information has been reliable in the past, the police are likely to accept his identification on its face and then may attempt to suggest the suspect's guilt to the witness. The informant plays no role in an on-the-scene confrontation.

40 On the possibility that a due process test could be applied to on-the-scene confrontations, see note 16 supra. 
testimony will be irretrievably lost. ${ }^{41}$ In order to avoid such loss, a rule governing on-the-scene confrontations should be explicit and easily understood. ${ }^{42}$ With such a guideline opportunities for the type of police practices that troubled the Wade court should not arise.

A possible rule to govern on-the-scene confrontations is: ${ }^{43}$ the police may conduct an on-the-scene confrontation within thirty minutes after the commission of a crime ${ }^{44}$ and within fifteen blocks of the scene ${ }^{45}$ if the offender fled on foot, or within thirty minutes and thirty blocks if the witness described the getaway car. Only suspects seized within these limits and who reasonably resemble the description given by the witness may be subjected to an on-the-scene confrontation. ${ }^{46}$

Confrontations conducted at police headquarters, however, should be attended by counsel. When a suspect is returned to police headquarters, rather than a local station, ${ }^{47}$ the policemen accompanying the suspect have stopped their search. Detention of the suspect until counsel is obtained will not impair voluntarily abandoned search procedures, whereas one officer holding a suspect at the scene of the crime cannot continue his search. Also, detention at headquarters implies that the police have specifically focused their attention on that suspect, ${ }^{48}$ and the elements of suggestiveness increase correspondingly. A confrontation at a local station may be solely for convenience, especially if the witness reported the crime at that station, and should not be subject to this limitation if conducted within thirty minutes of the crime. Exceptions to the general rule can be made for the extraordinary case such as a dying witness. This rule ${ }^{49}$ has the advantages

41 See id.

42 Miranda warnings are an example of an explicit rule governing police practices. See Miranda v. Arizona, 384 U.S. 436, 444-45 (1966).

43 See note 21 supra.

44 The time allowed for a search is based on the official pursuit procedures of the Philadelphia Police Department. The Philadelphia Police can saturate the area in which the crime was committed within a very few minutes by radio-dispatching patrol cars to predetermined search locations. Reply to Questionnaire, note 34 supra. These procedures suggest that searches conducted by police departments of large cities need not exceed 30 minutes. Beyond this time, it is likely that the offender has fled the area; he probably will not be found among the suspects seized in the vicinity of the crime after 30 minutes. Whenever on-the-scene identifications are allowed subsequent to termination of a fast pursuit, there arise opportunities for harassment and mistaken identification of favorite suspects arrested independently of the fast pursuit.

45 This proposed rule applies to on-the-scene confrontations in urban areas. In suburban and rural areas, the distince limitation should be adjusted accordingly.

46 If the police are allowed several hours and a large portion of a city in which to locate a suspect, the police could easily resort to round-up tactics.

47 This Comment defines the term "police headquarters" as the central executive and administrative offices normally located in the "downtown" area of a city. The term "local station" refers to neighborhood police stations, one of which will normally be within the vicinity of a crime requiring an on-the-scene confrontation.

48 See Escobedo v. Illinois, 378 U.S. 478 (1964).

49 The rule should also require the police to maintain records on the conduct of each search, such as taping radio dispatches, orders, and responses from squad cars, in order to enforce these limits. 
of allowing a good faith confrontation and prevents borderline cases involving difficult issues of credibility. It limits on-the-scene confrontations to those suspects among whom the police may reasonably expect to find the actual offender. At the same time, it provides minimum potential for the exercise of police and informant malice or harassment practices. ${ }^{50}$

\section{CoNCLUSION}

Some on-the-scene confrontations conducted in the absence of counsel should be permissible, not because of the increased reliability of resultant identifications, but because they are not inherently open to police malpractice and at the same time are necessary for efficient administration of law. But there should be a carefully delimited line which places a proper balance between the problems aimed at in Wade and the problems in excluding as evidence prompt on-the-scene identifications.

50 A test of probable cause for arrest would eliminate round-up arrests. However, this Comment is concerned partly with the effects of not extending $W$ ade to prompt on-the-scene confrontations. The proposed rule buttresses a requirement of probable cause for arrest without unduly hampering fair and efficient law enforcement. 